\title{
MYH1 Gene
}

National Cancer Institute

\section{Source}

National Cancer Institute. MYH1 Gene. NCI Thesaurus. Code C112130.

This gene plays a role in muscle contraction. 